11. If forced to visit England on sick leave, the assistantsurgeon receives $£ 126$ annually, less income-tax.

12. After seventeen years' service, he may retire on a pracion of $£ 190$ from the Government.

13. This not being practicable, a Medical Retiring Fund has been instituted, to which he is forced to subscribe each month. The Madras fund is in a healthy condition; the Bengal less so; the Bombay, while demanding a subscription of $\$ 31$ per ann., can only offer 112 as an annuity after seventeen years; and for this there are two or three applicants generally waiting.

14. These facts, which are not intimated by the authorities on appointment, should deter any one from entering the Bombay Presidency.

15. If not sufficient, let it be known that each assistantsurgeon is required to serve two years in the cruizers of the Indian navy, where all the discomforts of a small ship, hot climate, the worst cabin, \& $c_{\text {, }}$, have to be endured.

16. There are certain places the assistant-surgeon may be sent to where he most usually loses his health-Burmah, Arra can, the Persian Gulf, Scinde.

17. As money will only go half as far in India as it will in Fngland, this should be kept in mind when taking the pay into consideration.

18. On the whole, a medical officer, with capital to start with, if he remain single, may manage to live without getting into debt. If he marries, it is little better than beggary.

19. These things are not found out till the assistant-surgeon has been in India. Capital gone, opportunities at home lost, he is obliged to stay.

20. The Indian service requires, to make it worth entering, better pay, particularly for assistant-surgeons; a step of rank promotion to full surgeon, not in fifteen or seventeen years, bu in half that time; a furlough at the end of seven years, with enough to live on, in England; retiring allowances, withou having to pay for them more than the same would cost in an insurance office.

The Indian service thus might be made worth the attention of the best men from our schools and colleges. As it is, the Queen's English service, under the new Warrant, is infinitely preferable.

I am, Sir, your obedient servant,

Bombay, Dec. 1858 QUID PRO QUO.

\section{NOVEL SUBSTITUTE FOR A FEMALE CATHETER.}

To the Editor of THE LANCET.

SIn,-Observing in THE LANCET of last week a letter from Dr. Duke under the above heading, and thinking the bint might be of service to some of your readers who may happen to be placed in similar circumstances, I beg to state that, having to evacuate the bladder of a patient residing at a distance, whom I delivered by craniotomy, and having forcotten my pocket-case, I directed a common clay tobacco-pipe to be procured, six inches in length (unsmoked of course), glazed on the end, and with a large bore; this I besmeared with lard, and by means of a little pressure on the hypogastric region, drew off my patient's urine quite as effectually as if I had used a less uncouth and unprofessional instrument. This, I think, has some advantages over Dr. Duke's ingenious contrivance, in its being more readily obtained, more easily introduced, and less likely, I fancy, to abrade the mucous lining of the urethra, if a smooth pipe is selected, and, withal, much more simple, and inite efficacious. A further improvement might be made by inserting a piece of wire as a stilette, if that were to be readily obtained.

I am, Sir, your oledient servant,

Dudley, March, 1859

$$
\text { J. S. PAPE. }
$$

\section{THE NORWICH BOARD OF GUARDIANS AND THE LUNACY COMMISSIONERS. To the Editor of THE LANCET.}

SIR,-My position as deputy chairman of the Norwich board of guardians has of necessity thrown me much in the way of lunatics and Lunacy Commissioners. My acquaintance with both is likely to be further extended, since I have latterly become one of the proprietors of a private establishment near this city. Past experience justifies the assertion that the condition of the lunatic has been materially improved by the ezertions of the Commissioners in Lunacy; bnt it is to be regretted that in many respects their power is limited, and they are at present unable to enforce by law such recommendations as are for the benefit of the lunatic. It is to be hoped that the new Government Bill, with Mr. Tite's Committee, will prove effectual in framing such laws as can be carried out not only in word, but in spirit. A curious case of this kind, in which the law of the Act prevailed over the spirit of the Act, has recently occurred in this place. To a slight, very slight, degree I am personally and pecuniarily interested in this case, which I record not as the exposition of a mere private grievance, but that of a great and alarming public one, by which we discover that, under the existing laws of lunacy as relating to private houses, the Commissioners, whatever may be their opinion of some of these houses, have no power to prevent the reception of patients therein while the licence of the justices remains in force.

My illustration of the evil of such limited power is as follows: During the latter part of last year I became (with my son and a lady) one of the proprietors of an asylum, known as the Heigham Retreat. At that time, Dr. Copeman, of this city, was the visiting physician to the establishment; but upon my accession, he judred it orudent to secede, and lent his name and infuence to the fortunes of a private hospital for the in sane, known as the Grove, Catton. His previous knowledge of the patients gave him a certain infuence with their relatives, which it was natural he should exert in favour of his new allegiance. As a mere matter of business, that was all fair enough. and Dr. Copeman's commercial honour remained untarnished. I make no complaint, but proceed with my statement. In aue time, as was anticipated, an application was made to the Commissioners for what is termed as "consent" for the removal of a patient from one asylum to another,-viz., from the Retreat, to the Grove at Catton. And now mark: for reasons best known to the Commissioners, and only to be guessed at by others, they, heedless of Dr. Copeman's name and influence refused to give such "consent." After such refusal, could you, Sir, believe it possible that, by working the Lunacy Laws with a little tact, that unhappy lunatic is at this moment patient in that forbidden house? - that the Commissioners sit corrected, and are bearded in Whitehall-place, and laughed at as not having power to enforce their own recommendations. The reader will naturally ask, "Put how can this be done?" $\mathrm{Oh}$, nothing easier! Half-an-hour is ample time to upset the reto of the Commissioners. The patient goes through the faree of being discharged; he is then subjected to fresh medical examinations, has a fresh order signed, and, heigh presto! he is again a legal lunatic, and the house with the ban of the Commissioners upon it has a legal right to receive him; but you, Sir, will agree with me, that the less we say about the moral right. or the judgment of those friends who have been hoodwinked into such an ontrage against their relative, the better.

On public grounds I report this case. I know of no bette means of calling the attention of the Legislature to this axomalous law than through the pages of your journal; and while seek no publicity, I am not ashamed of my name, but am, Sir, Yours very obediently,

Wrarch, 1859 .

WM. WILDE,

\section{THE NEW MTLITARY MEDICAI SCHOOI.} To the Editor of THE LAITCET.

Sis, - I have to thank you for inserting my previous letter in reference to the proposed Military Medical School. Since that was published, I have been informed by two army surgeons that this school will be more irksome to the "probationers" than ever Chatham was in its worst days of military buliying. Are all who now seek the Army Medical Department to be subjected to a similar ordeal of tyranny?-that is the question. If the Director-General wishes to get the best men, that is not the right way to go about it. Schooling, buliying, and espionage will not do in these days. "Tempora mutantur, et nos mutamur in illis."

March, 1859 .

I am, Sir, your obedient servant,

A Last Year's Mar.

\section{To the Editor of The LANCET.}

Sir, - I have read the letter of "A Last Year's Man," in THE LACOET of the 26 th ult. The students of the three divi sions of the United Kingdom have the case of the proposed Military Medical School there clearly set before them. Let them take up the matter themselves, by holding meetings in their respective schools, and protesting their opposition to the scheme. If clinical military medicime and surgery cannot be taught at it, why are fully-qualified men to be subjected to this compulsory schooling? The students of every school 